\title{
Social Media Attributes and Sustainable Indigenous Tourism Among Mah Meri Community in Carey Island, Malaysia
}

\section{Zuliah Abd Hamid, Shazali Johari, Puvaneswaran Kunasekaran}

To Link this Article: http://dx.doi.org/10.6007/IJARBSS/v11-i16/11233 DOI:10.6007/IJARBSS/v11-i16/11233

Received: 05 July 2021, Revised: 08 August 2021, Accepted: 25 August 2021

Published Online: 12 September 2021

In-Text Citation: (Hamid et al., 2021)

To Cite this Article: Hamid, Z. A., Johari, S., \& Kunasekaran, P. (2021). Social Media Attributes And Sustainable Indigenous Tourism Among Mah Meri Community In Carey Island, Malaysia. International Journal of Academic Research in Business and Social Sciences, 11(9), 261-270.

Copyright: (c) 2021 The Author(s)

Published by Human Resource Management Academic Research Society (www.hrmars.com)

This article is published under the Creative Commons Attribution (CC BY 4.0) license. Anyone may reproduce, distribute, translate and create derivative works of this article (for both commercial and non-commercial purposes), subject to full attribution to the original publication and authors. The full terms of this license may be seen at: http://creativecommons.org/licences/by/4.0/legalcode

Special Issue Title: Contemporary Issues in Tourism and Hospitality industry, 2021, Pg. 261 - 270

Full Terms \& Conditions of access and use can be found at http://hrmars.com/index.php/pages/detail/publication-ethics 


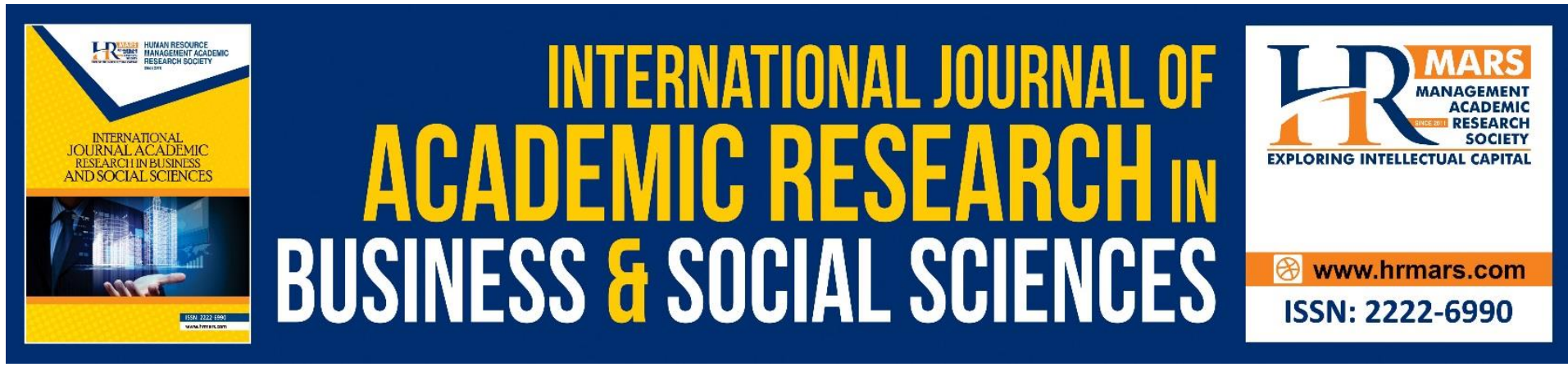

\title{
Social Media Attributes and Sustainable Indigenous Tourism Among Mah Meri Community in Carey Island, Malaysia
}

\section{Zuliah Abd Hamid ${ }^{1}$, Shazali Johari², Puvaneswaran Kunasekaran ${ }^{3}$}

${ }^{1}$ Faculty of Hotel and Tourism Management Universiti Teknologi MARA, Cawangan Selangor, Malaysia, ${ }^{2}$ Faculty of Human Ecology, University Putra Malaysia, Serdang, Selangor, Malaysia, ${ }^{3}$ Faculty of Social Sciences and Leisure Management, Taylor's University, Malaysia

Email: zulia954@uitm.edu.my

\begin{abstract}
This study aims to understand the role of social media in influencing the sustainable indigenous tourism practice. This research contributes to the scope of indigenous tourism and social media. A deductive approach is used to identify the level of the social media attributes, namely adoption, participation, interactivity and sharing. Past studies relevant to social media technology and sustainability were analysed and discussed. It is evident that the existing literature heavily supports the need for social media in tourism development. Local communities, especially the indigenous people, are urged to utilise the virtual platform to sell their tourism products. However, the unavailability of community capacity often hinders them to used social media at the desired level. Thus, a critical understanding of social media and sustainable tourism conceptualisation is highlighted to provide a holistic perspective. The construct of social media in this study shows a high level of consistency. The finding contributes to a scale development on social media and tourism from indigenous people perspectives.
\end{abstract}

Keywords: Indigenous Tourism, Social Media, Adoption, Participation, Interactivity, Sharing, Mah Meri

\section{Introduction}

With many nature attractions dominating the Malaysian tourism sector, many tourism studies in Malaysia have focused on island tourism and ecotourism. The only limited secondary body of literature explores indigenous aspects of tourism. Recently, many countries in the region, including Malaysia, have recognised the potential for indigenous tourism to diversify the tourism industry and rural economic development. Malaysia is one of the countries in the Asian region with heavy internet users, with an average of 12 hours per day (Malaysian Communications and Multimedia Commission, 2017). The way of life and the interaction of people have changed rapidly since the development of technology as well as the existence of social media (Cooper et al., 2017; Tiago \& Veríssimo; 2014). Social media, such as Facebook 
and Instagram, are the most commonly used social tools among Malaysians (Yusop and Sumari, 2013).

The development of information and communication technology, which involves the usage of social media and internet tools, has brought awareness to millions of people. This has created new chances and choices for many people to communicate. However, this has not been verified in the context of indigenous tourism. In the hospitality and tourism industry, the common problem of the research topic lies in concerns the use of information technology for various purposes. Social media have been increasingly adopted by hospitality and tourism companies and used by tourists. However, this study shows that social media in many hospitality and tourism sectors lack sufficient attention from academia (Lu et al., 2018). As Lu et al $(2018$, p.11) stated, the "interactive role of social media throughout the entire tourism experience has not received attention although the effects of social media in every stage of travel decision-making have been explored.".

The Mah Meri refers to "forest people" who are part of the Orang Asli (the aborigines), which are residing at Carey Island, Selangor, since the mid-1800s (Isa et al., 2016; Lai, 2011). They were previously migrated to Selangor from Southern Johor in order to escape from enemies (Masron, Masami, \& Ismail, 2013). They are traditionally rural peoples living near the coastal area and are acknowledged as Orang Laut (ocean people) since they reside near the sea (Masron et al., 2013). They are also called 'the Mask Man' and produces traditional wood carvings and mask sculpture. Their wood carvings craftsmanship has won several accolades under the UNESCO Seal of Excellence programme. On the other hand, the women in Mah Meri were involved in weaving activities (Kunasekaran et al., 2013).

Tourism has inevitably impacted the Mah Meri community (Majin, Azman, \& Jailani, 2011). In term of socio-economic impacts, tourism contributes to income and uplift the quality of life to the Mah Meri community. Cultural impacts have been found to impact the Mah Meri community's quality of life (Majin, Azman, \& Jailani, 2011). Thus, the attitude towards tourism development in Carey Island is positive, and they support tourism. Tourists commonly use social media to make travel decisions, pre-trip planning, sharing and exchange information about their trips (Edwards et al., 2017; Pabel \& Prideaux, 2016; Lu et al., 2018). For example, Pabel and Prideaux (2016) conducted a study to understand the use of social media for information searching before the trip begins for a small coastal destination in Port Douglas, Queensland, Australia. However, Howison et al (2015) stated that tourists use social media pre and post-travels. Besides networking, social media also helps tourists integrate and share their experiences, reviews, and comments and search for relevant information at their fingertips (Ly and Ly, 2020). In addition, advanced development in social media technology automatically assists the tourists from their preparation of travel until post tourism experiences (Parra et al., 2011; Wang et al., 2002). In Malaysia, social media is used to help tourists select tourism destinations (Lim, Ramayah, Teoh, \& Cheah, 2017).

The use of social media is prevalent among millennials or Generation Y (Xiang, Magnini, \& Fesenmaier, 2015). It is often used to express ideas, emotions, and experiences innovatively (Luo \& Zhong, 2015). A study conducted by Ellison, Steinfield, and Lampe (2007) showed that college students use Facebook to build and maintain a friendship. On the other hand, Cheng et al. (2016) examined how social media influence the relationship between ecotourism and the natural environment. Some studies reported that social media is a tool for rural development (Gilbert et al., 2008). For instance, it is useful to promote peripheral areas, reach more international tourists, and change a famous domestic destination in Ōkunoshima Island in Japan into an international destination (Usui, Wei, \& Funck, 2018). 


\section{Problem Statement}

Although the development of social media has received increased attention from tourism researchers, very little empirical evidence has been used to examine social media usage in the community, particularly indigenous tourism (Mkono, 2016). To the best knowledge of the researcher, there are limited tourism studies on the use of social media among indigenous people. Most of the researches on social media are concentrated on the consumer's perspective. Therefore, stakeholders are still looking for answers to this question since it has not been solved practically or academically. Similarly, there are gaps in contemporary literature on the use of social media among the local indigenous community. Moreover, analysing the uses and applications of information and communication technology (ICT) in indigenous tourism has been relatively less researched by past studies. For example, Zeng and Gerritsen (2014) showed that research on social media in tourism is still in its infancy. They suggested a comprehensive inquiry into the influence and impact of social media should be undertaken, particularly relates to communities and economic benefits. Therefore, further contributions to the literature are needed. This research examines the social media attributes (adoption, participation, interactivity and sharing ) that could influence sustainable indigenous tourism. Besides, this study aims to examine the direct effects of social media attributes on sustainable indigenous tourism among the MahMeri community.

\section{Methods}

Quantitative research design is a survey technique used in research to measure specific characteristics through a structured questionnaire from many representative samples so that the result can be generalised for the entire population (Fischer et al., 2014). As implemented in this study, the researcher used a structured questionnaire to analyse the influence and level of social media on sustainable indigenous tourism. This design is applied in the study as it enables the researcher to gather relevant information from respondents who are considered to be representatives of the entire population (Creswell, 2011).

Data Collection, Research Instrument

The target population for this study is Mah Meri communities in Carey Island. The statistics derived from the Department of Orang Asli Development of the year 2019 indicated that the total population of the Mah Meri community in Carey Island is 3762 . The calculator estimates 349 Mah Meri people as a suitable sample size for this study (based on the Mah Meri community statistics provided by the Department of Orang Asli Development, 2019).

\section{Data Analysis Method}

The quantitative data analysis process consists of several stages: coding the response, screening the collected data, and selecting the suitable data analysis process (Sekaran and Bougie, 2013). The data screening process was performed to detect the errors in the data entry and investigate how the collected data appropriately meets the statistical assumptions, including descriptive statistics of constructs, missing data, treatment of outlier, normality and reliability. Several statistical analyses of SPSS were applied in this study to examine the data and hypotheses testing. Finally, Structural Equation Modelling (SEM)- PLS (Partial Least Squares) analysis was executed to evaluate exogenous and endogenous constructs' relation. After the data collection process, coding was used to systematically and easily key the data into SPSS 21 (data analysis software) (Zikmund, 2003). The data was coded by assigning characters symbols (using numerical symbols) and edited before entering SPSS. 
The data screening process was applied in this study to ensure that the characteristics of the data do not result in negative effects on the outcomes. It is also known to ensure clean, valid, reliable, and ready to be analysed before proceeding with statistical analysis. This process is essential to avoid human error in the data entry process, evade suspicious outliers (which can be smaller or larger than most of the observations), detect the missing values and test the assumptions before executing the actual tests (Stephen, 2015).

\section{Result}

The result demonstrated that social media directly relates to sustainable indigenous tourism where the path coefficient $(\beta)$ at 0.393 and t-value is 5.320 (greater than 1.96). Thus, this hypothesis is supported. This finding is also supported by Cheng et al. (2017), Hussain et al. (2019), Parra et al. (2011) and Wang et al. (2002). They indicated the positive and significant relationship between social media attributes and the sustainability of tourism destinations. Similarly, the studies Liu et al. (2020), Chung and Khoo (2015) and No and Kim (2015) revealed that social media plays an essential role in communicating, interact and influence the tourist's behaviour and tourism development. However, the study by Javed et al. (2020) indicated social media as a source of tourism promotion illustrated a non-significant relationship with the prediction of tourists' behavioural intention and actual behaviour.

Figure 1: Reflective Assessment (PLS) - Social Media

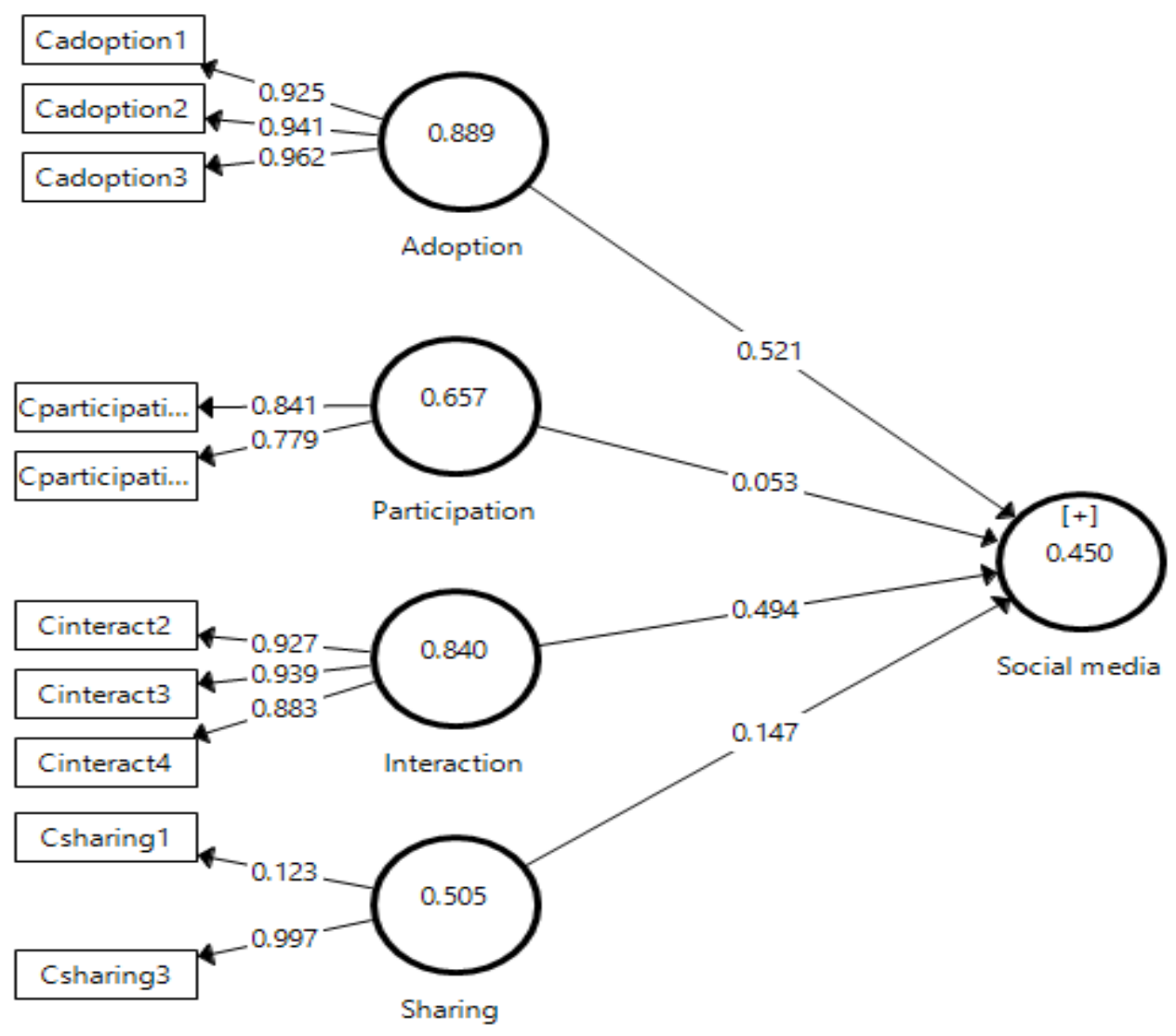

A reliability test is essential in research to evaluate the item's internal consistency used in the survey instrument. The Cronbach's alpha reliability coefficient value should be between 0 and 
1. Whenever the value is closer to 1.0 , it demonstrated a greater consistency among items used in the scale (Ursachi et al., 2015; Gliem and Gliem, 2003). Table 1 illustrated the summary of constructs and reliability results. The reliability value for all the constructs in this study ranged from 0.65 to 0.91 . Composite reliability analysis was also conducted to calculate the constructs' reliability coefficients. The summary of the composite reliability based on the standardised factor loadings generated from the final revised structural model demonstrated that all the constructs have good factor loading values exceeding 0.50 .

Table 1- Summary of Constructs and Reliability Results.

\begin{tabular}{|c|c|c|c|}
\hline Variables & Original of items & $\begin{array}{c}\text { Cronbach's } \\
\text { Alpha }\end{array}$ & $\begin{array}{c}\text { Composite } \\
\text { Reliability }\end{array}$ \\
\hline Social Media: Adoption & 4 & 0.800 & 0.960 \\
\hline Social Media: Participation & 3 & 0.810 & 0.940 \\
\hline Social Media: Interact & 4 & 0.770 & 0.793 \\
\hline Social Media: Sharing & 3 & 0.781 & 0.835 \\
\hline
\end{tabular}

\section{Convergent Validity}

The first step in analysing the reflective measurement model is calculating the indicator loadings of all reflective constructs. Any item or sub-construct with an indicator loading (value) above 0.70 is considered a reliable item to the study because it explains more than 50 per cent of the indicator's variance (Hair et al., 2018). Table 2 shows the indicator loadings before after deletion were made.

Table 2: Loading before and after deletion.

\begin{tabular}{|c|c|c|c|c|}
\hline Constructs & Dimensions & Item & $\begin{array}{l}\text { Loadings / Weights } \\
\text { (before) }\end{array}$ & $\begin{array}{l}\text { Loadings / Weights } \\
\text { (after) }\end{array}$ \\
\hline \multirow{14}{*}{ Social Media } & \multirow{4}{*}{ Adoption } & Cadoption 1 & 0.907 & 0.925 \\
\hline & & Cadoption 2 & 0.943 & 0.941 \\
\hline & & Cadoption 3 & 0.953 & 0.962 \\
\hline & & Cadoption 4 & 0.391 & \\
\hline & \multirow[b]{3}{*}{ Participation } & Cparticipation 1 & 0.352 & \\
\hline & & Cparticipation 2 & 0.804 & 0.841 \\
\hline & & Cparticipation 3 & 0.761 & 0.779 \\
\hline & \multirow{4}{*}{ Interaction } & Cinteract 1 & 0.28 & \\
\hline & & Cinteract 2 & 0.901 & 0.927 \\
\hline & & Cinteract 3 & 0.929 & 0.939 \\
\hline & & Cinteract 4 & 0.856 & 0.883 \\
\hline & \multirow{3}{*}{ Sharing } & Csharing 1 & 0.065 & 0.123 \\
\hline & & Csharing 2 & -0.066 & \\
\hline & & Csharing 3 & 0.995 & 0.997 \\
\hline
\end{tabular}

The next step in assessing the reflective measurement model is to examine the convergent validity through Average Variance Extracted (AVE). Hair et al. (2018) and Valerie (2012) was pointed out that the minimum acceptable AVE value should be greater than 0.5 . This explains that constructs used elaborate 50 percent and more of the variance of the items that make 
up the construct. In this study, all AVE values were above 0.50 and within the recommended value. Hence, the second indicator of convergent validity (AVE requirement) was also met.

Table 3: Convergent Validity Analysis

\begin{tabular}{|c|c|c|c|c|c|}
\hline Construct & Item & $\begin{array}{c}\text { Loadings / } \\
\text { Weights (after) }\end{array}$ & AVE & Composite Reliability & $\begin{array}{c}\text { Cronbach } \\
\text { Alpha }\end{array}$ \\
\hline \multirow{10}{*}{$\begin{array}{l}\text { Social } \\
\text { Media }\end{array}$} & Cadoption 1 & 0.925 & \multirow{3}{*}{0.889} & \multirow{3}{*}{0.960} & \multirow{3}{*}{0.800} \\
\hline & Cadoption 2 & 0.941 & & & \\
\hline & Cadoption 3 & 0.962 & & & \\
\hline & Cparticipation 2 & 0.841 & \multirow{2}{*}{0.657} & \multirow{2}{*}{0.940} & \multirow{2}{*}{0.810} \\
\hline & Cparticipation 3 & 0.779 & & & \\
\hline & Cinteract 2 & 0.927 & \multirow{3}{*}{0.840} & \multirow{3}{*}{0.793} & \multirow{3}{*}{0.770} \\
\hline & Cinteract 3 & 0.939 & & & \\
\hline & Cinteract 4 & 0.883 & & & \\
\hline & Csharing 1 & 0.123 & \multirow{2}{*}{0.505} & \multirow{2}{*}{0.835} & \multirow{2}{*}{0.781} \\
\hline & Csharing 3 & 0.997 & & & \\
\hline
\end{tabular}

Analysis of composite reliability is a third step in evaluating the reflective measurement model assessment. The range of the composite reliability is between 0 to 1 . Studies by Hair et al. (2018; 2014) indicated that the reliability values between 0.60 to 0.70 are considered acceptable, while the values between 0.70 to 0.90 are assumed satisfactory to good. Table 3 also demonstrated the outcomes of the analysis of convergent validity. The findings indicated that all composite reliability values were between 0.50 to 0.97 . Thus, it was concluded that all constructs in this study were adequate and had high internal consistency.

\section{Discussion, Conclusion and Implications of Research}

The use of social media is not only popular in information technology, but the application of social media in the tourism and hospitality sector has also grown rapidly (Sarkar \& George, 2018). It has been accepted as an important tool. Social media is increasing tremendously (Hussain, Chen, \& Nurunnabi, 2019) because many tourists tend to use the internet to access travel information and plan their travel beforehand. Thus, social media becomes the main source of tool for people to plan their trips beforehand. Social media channels emerging in the past few years, with the advent of Web 2.0, include social networks, photo and video sharing sites, wikis, blogs and online review sites. Such channels are of exponentially growing importance within the wider range ecosystem encompassing all the social media dimensions, including traditional channels such as mass media (Hanna, Rohm, \& Crittenden, 2011). Luo and Zhong (2015) stated as internet competencies progress, Social networking sites (SNSs) provide an interaction platform among tourists using electronic word-of-mouth (eWOM) and a tool for marketing. Pabel and Prideaux (2016) suggested that "the growth in the use of social media allied with increasing ownership levels of smartphones indicates that destination marketing organisations of small regional destinations need to pay greater attention to social media and its delivery systems, including smartphones. Some tourism studies highlighted that social media brings significant implications to local people, such as employment (Safko 2009; Xiang \& Gretzel, 2010; Hays et al., 2013). Today, information about hospitality companies is all day long (Bowen \& Baloglu, 2015). From a business perspective, information technology and the use of social media change the ways business organisations do business (Buhalis $\&$ 
Law, 2008; Jacobsen \& Munar, 2012). Social media provides a platform for tourism companies to interact with their clients to provide the best services (Howison et al., 2015). It also offers a destination marketing organisation (DMO) to reach global consumers at a lower cost (Hays et al., 2012).

\section{Conclusion}

From the reviews above, it is apparent that tourism brought both good and bad impacts to the destinations in three dimensions; economic, sociocultural, and environmental (Samah et al., 2012). To ensure long-term success, the local community should maximise tourism benefits and minimise tourism by-product by adopting a sustainable tourism development approach. Sustainable tourism development is proposed for a balanced economic, sociocultural, and environmental development approach with all stakeholders' concerted effort in understanding the best balance for the destination. Once the importance of social media is understood, utilising the tools for tourism development should be sustainable. This strategy will help the local community to avoid over-tourism, mass tourism and negative word-of-mouth issues.

\section{References}

Bowen, J., \& Baloglu, S. (2015). Common themes across social media research. Worldwide Hospitality and Tourism Themes, 7(3), 314-319.

Buhalis, D., \& Law, R. (2008). Progress in information technology and tourism management: 20 years on and 10 years after the Internet-The state of eTourism research. Tourism Management, 29(4), 609-623.

Cheng, M., Wong, I. A., Wearing, S., \& McDonald, M. (2017). Ecotourism social media initiatives in China. Journal of Sustainable Tourism, 25(3), 416-432.

Chung, N., \& Koo, C. (2015). The use of social media in travel information search. Telematics and Informatics, 32(2), 215-229.

Cooper, M., Thai, L. Q., Claster, W., Vafadari, K., \& Pardo, P. (2017). Social Media an Knowledge Transfer in Tourism: Five-Star Hotels in Philadelphia. In Knowledge Transfer to and within Tourism: Academic, Industry and Government Bridges(pp. 239-255). Emerald Publishing Limited

Creswell, J. W., \& Plano Clark, V. L. (2011). Designing and conducting mixed methods research (2nd ed.). Thousand Oaks, CA: Sage.

Edwards, D., Cheng, M., Wong, I. A., Zhang, J., \& Wu, Q. (2017). Ambassadors of knowledge sharing: Co-produced travel information through tourist-local social media exchange. International Journal of Contemporary Hospitality Management, 29(2), 690-708.

Ellison, N. B., Steinfield, C., \& Lampe, C. (2007). The benefits of Facebook "friends:" Social capital and college students' use of online social network sites. Journal of computer mediated communication, 12(4), 1143-1168.

Gliem, J. A., \& Gliem, R. R. (2003). Calculating, Interpreting and Reporting Chronbach's Alpha Hair, J. F., Sarstedt, M., Ringle, C. M., \& Gudergan, S. P. (2018). Advanced issues in Partial Squares Structural Equation Modeling. SAGE Publications

Hanna, R., Rohm, A., \& Crittenden, V. L. (2011). We're all connected: The power of the social media ecosystem. Business horizons, 54(3), 265-273.

Hays, S., Page, S. J., \& Buhalis, D. (2013). Social media as a destination marketing tool: its use by national tourism organisations. Current issues in Tourism, 16(3), 211-239. 
Howison, S., Finger, G., \& Hauschka, C. (2015). Insights into the Web presence, online marketing, and the use of social media by tourism operators in Dunedin, New Zealand. Anatolia, 26(2), 269-283.

Hussain, T., Chen, S., \& Nurunnabi, M. (2019). The role of social media for sustainable development in mountain region tourism in Pakistan. International Journal of Sustainable Development \& World Ecology, 26(3), 226-231.

Isa, S. S., Zakaria, H. M., \& Isa, S. S. (2016). From Cultural Activity to Cultural Tourism: A Case of Indigenous Community in Malaysia. In Regional Conference on Science, Technology and Social Sciences (RCSTSS 2014) (pp. 1009-1021). Springer, Singapore.

Javed, M., Tuckova, Z., \& Jibril, A. B. (2020). The Role of Social Media on Tourists' Behavior: An Empirical Analysis of Millennials from the Czech Republic. Sustainability. 12. 7735.

Kunasekaran, P., Gill, S. S., Talib, A. T., \& Redzuan, M. R. (2013). Culture as an indigenous tourism product of Mah Meri community in Malaysia. Life Science Journal, 10(3), 16001604.

Lai, W. T. (2011). Gender and livelihoods: a case study of the Mah Meri and the oil palm plantations of Carey island. Asian Journal of Women's Studies, 17(2), 66-95.

Lim, H. Y., Ramayah, Teoh, A. P., \& Cheah, J. H. (2017). Social media as a tool to help select tourism destinations: The case of Malaysia. Information Systems Management, 34(3), 265- 279.

Liu,Z., Mahraliyev, F., Lui, C., \& Schuckert, M. (2020). The roles of social media in tourists' choices of travel components. Tourist Studies. 20 (1).

Lu, Y., Chen, Z., \& Law, R. (2018). Mapping the progress of social media research in hospitality and tourism management from 2004 to 2014. Journal of Travel \& Tourism Marketing, 35(2), 102-118.

Luo, Q., \& Zhong, D. (2015). Using social network analysis to explain communication characteristics of travel-related electronic word-of-mouth on social networking sites. Tourism Management, 46, 274-282.

Ly, B., \& Ly, R. (2020) Effect of Social Media in Tourism (Case in Cambodia). Journal of Tourism Hospitality. 9:424.

Majin, J. J., Azman, I., \& Jailani, F. L. (2016). Support for Future Tourism Development, Quality of Life and Perceived Impacts of Tourism Industry Within Indigenous Community: Mah Meri of Carey Island, Malaysia. In Regional Conference on Science, Technology and Social Sciences (RCSTSS 2014)(pp. 1063-1073). Springer, Singapore.

Masron, T., Masami, F., \& Ismail, N. (2013). Orang Asli in Peninsular Malaysia: population, spatial distribution and socio-economic condition. J Ritsumeikan Soc Sci Humanit, 6, 75115.

Mkono, M. (2016). Sustainability and Indigenous tourism insights from social media: worldview differences, cultural friction and negotiation. Journal of Sustainable Tourism, 24(8-9), 1315-1330.

No, E., \& Kim, J. K. (2015), Comparing the attributes of online tourism information sources, Computers in Human Behavior, Vol. 50, pp. 564-575.

Pabel, A., \& Prideaux, B. (2016). Social media use in pre-trip planning by tourists visiting a small regional leisure destination. Journal of Vacation Marketing, 22(4), 335-348., B. (2016). Social media use in pre-trip planning by tourists visiting a small regional leisure destination. Journal of Vacation Marketing, 22(4), 335-348.

Safko, L., \& Brake, D. K. (2009). The social media bible. Hoboken. NJ: John Wiley \& Sons. Sakamoto. 
Samah, A. A., Ahmadian, M., Gill, S. S., Hendijani, R. B., \& Babolian, R.(2012). Factors affecting educational tourism development among local communities in the Klang Valley, Malaysia. Life Science Journal, 9(4), 3298- 3303.

Sarkar, S. K., \& George, B. (2018). Social media technologies in the tourism industry: an analysis with special reference to their role in sustainable tourism development. International Journal of Tourism Sciences, 1-10.

Sekaran, U., \& Bougie, R. (2013). Research Methods for Business: A Skill-Building Approach (6th ed.). Chichester, West Sussex: John Wiley \& Sons, Inc.

Stephen, D. (2015). Data Screening using SPSS for Beginner: Outliers, Missing Values and Normality. Institute of Borneo Studies Workshop Series 2016.

Tiago, M. T. P. M. B., \& Veríssimo, J. M. C. (2014). Digital marketing and social media: Why bother?. Business Horizons, 57(6), 703-708.

Ursachi, G., Horodnic, J.A., Zait, A. (2015). How reliable are measurement scales? External factors with indirect influence on reliability estimators. Procedia Economics and Finance.20. 671-686.

Usui, R., Wei, X., \& Funck, C. (2018). The power of social media in regional tourism development: a case study from Ōkunoshima Island in Hiroshima, Japan. Current Issues in Tourism, 21(18), 2052-2056.

Valerie, F. (2012). Re-Discovering the PLS Approach in Management Science. Management.15 (1). 101- 123.

Wang, Y., Yu, Q. \& Fesenmaier D.R. (2002). Defining the virtual tourist community: Implications for tourism marketing. Tourism Management. 23(4):407-417

Xiang, Z., \& Gretzel, U. (2010). Role of social media in online travel information search. Tourism management, 31(2), 179-188.

Xiang, Z., Magnini, V. P., \& Fesenmaier, D. R. (2015). Information technology and consumer behavior in travel and tourism: Insights from travel planning using the internet. Journal of Retailing and Consumer Services, 22, 244-249.

Zeng, B., \& Gerritsen, R. (2014). What do we know about social media in tourism? A review. Tourism Management Perspectives, 10, 27-36.

Zikmund, W. G., Babin, B. J., Carr, J. C., \& Griffin, M. (2013). Business research methods. Cengage Learning 